DOI 10.31558/2519-2949.2018.3.4

УДК 328.185-048.66:323.212/.213(437)

Кабанцева І. А., Державний заклад «Південноукраӥнський національний педагогічний університет імені К. Д. Уиинського»

\title{
«ТРЕТІЙ СЕКТОР» ЧЕХІЇ ЯК АКТОР АНТИКОРУПЦІЙНОЇ ПОЛІТИКИ
}

Відзначено, щзо попри швидкі темпи реформування Чехії в останні три десятиліття, високий рівень корупиї стримує ефективну модернізацію країни. Акцентовано, щуо чеське громадянське суспільство виступає активним лобістом антикорупиійних ініціатив. У статті: 1) визначено рівень розвитку, ступінь сформованості громадянського суспільства Чехії; 2) досліджено міру руйнівного впливу деструктивного інституту корупиї в циій краӥні; 3) з'ясований вплив конструктивного інституту чеського громадянського суспільства Чехії на деструктивний інститут корупиії. Зауважено: попри високий рівень корупиії в Чехії, тут, на відміну від низки краӥн Центрально-Східної Європи, антикорупиійні масові акиї протесту мають поодинокий характер. Натомість значними є антикорупційні ініціативи чеського «третього сектора», зокрема, антикорупиійної платформи «Rekonstrukce STATU» (RotS), Transparency International Česká republika, «Frank Bold», «Zindex», «Oživeni» та ін. Проаналізовано діяльність антикорупиійної платформи «RotS», яка об'єднує понад 20 чеських НУО та сконцентрована на розробиі антикорупиійних законопроектів. Відзначено, щчо законотворчі пропозииї̈ «RotS» зумовили появу низки громадських ініціатив у інших країнах Центрально-Східної Свропи (наприклад, «Ez a minimum a korrupció ellen» в Угорщині, «Štrngám za zтепи!» у Словаччині та ін.). У статті досліджено антикорупчійні ініціативи організачії правозахисного типу «Frank Bold», яка забезпечує юридичне консультування, захист у справах про корупиію, лобіює законопроекти, спрямовані на контроль за урядом, забезпечення прозорості прийняття публічних рішень, найперше - щодо державних контрактів. Вивчено діяльність НУО «Zindex» (спеціалізується на виявленні корупиії в державних закупівлях) $i$ «Oživení» (здійснює антикорупиійне консультування, антикорупиійний аудит, вироблення антикорупиійних стратегій тощо). Аргументовано: досвід Чехії засвідчує значний потениіал громадянського суспільства в протидї корупиії. Без акторів громадянського суспільства в Чехії унеможливилося б публічне обговорення теми корупиї та змушування політиків уважати иі питання релевантними.

Ключові слова: Чехія, корупиія, антикорупщійні НУО, антикорупиійні громадські ініціативи.

Останні три десятиліття в історії Чехії наповнені знаковими для розвитку країни подіями: «Оксамитова революція» (1989), мирний поділ держави (1993), прийняття до НАТО (1999) та ЄС (2004). У Чехословаччині було в найкоротшім часі 3-поміж країн Центрально-Східної Свропи змінено тоталітарну систему [7, с. 283]. Чехія першою в регіоні підписала договір про асоціацію з СС, у такий спосіб задекларувавши свої євроінтеграційні прагнення. Г. Зеленько відзначає, що «Чехію називають “майже ідеальною лабораторією” постсоціалістичної трансформації. На відміну від решти країн, Чехія досягла найвищого рівня консолідації політичних сил щодо процесів реформування» [3, с. 23]. Водночас проблема корупції не оминула цю країну і чеське громадянське суспільство виступає активним лобістом антикорупційних ініціатив.

Для того, аби оцінити антикорупційну активність чеського громадянського суспільства, найперше виконаємо два завдання: 1) визначимо рівень розвитку, ступінь сформованості громадянського суспільства Чехії; 2) дослідимо, наскільки значним для Чехії $є$ руйнівний вплив деструктивного інституту корупції. Аналіз двох поставлених питань уможливить перехід до з'ясування того, наскільки значним є вплив конструктивного інституту громадянського суспільства Чехії на деструктивний інститут корупції в цій країні. Окреслене завдання практично не перебувало в полі досліджень вітчизняної політичної науки. Проблематика еволюції громадянського суспільства та корупційні практики у Чехії вивчалися українською наукою (Г. Зеленько, Н. Марадик, В. Приходько, І. Ткаченко та ін.), але вплив цих двох неформальних інститутів (громадянського суспільства та корупціi) один на одного лише починає вивчатися. Більше уваги цьому приділено у доробку чеських авторів (П. Кірілі, В. Кріж, В. Ріхачкова та ін.) 
Формування громадянського суспільства у будь-якій країні є питанням, пролонгованим в часі. Новітне чеське громадянське суспільство, на нашу думку, сформувалося як результат кількастолітньої еволюції громадянських ініціатив, які ми означимо як етап протогромадянського суспільства. Вкажемо на знакові події, які слугували справі формування новітнього чеського «третього сектора»:

- формування чеського протогромадянського суспільства, уважаємо, почалося ще наприкінці XVIII ст.: «Приватне вчене товариство» (1770 р. засн.; пізніша назва - Королівське чеське товариство наук), згуртування провідних чеських діячів науки та культури довкола створеного в Празі видавництва «Чеська енциклопедія» (1790 p. засн.) i т. д. Одним із найбільших представницьких інструментів, який слугував справі культурно-національної модернізації [1, с. 203], було товариство «Чеська матиця» (1831 р. засн.);

- Чехословаччина є серед тих країн Центрально-Східної Свропи, яка зазнала в 1918-1939 рр. «першої хвилі демократизації» [3, с. 14]. І. Ткаченко відзначає, що «позитивний імпульс розвитку громадського сектора дали події 1918 р., які призвели до виникнення Чехословацької держави» і від цього часу, на думку дослідника, можна говорити про неперервний розвиток громадянського суспільства $з$ перервами на нацистську окупацію та радянський режим [9, с. 278]. На цей історичний період припадає інтенсивний розвиток громадських організацій, політичних партій, розширення громадянських і політичних прав. Наприклад, у 1938 р. на чеських землях налічувалося понад 9 тис. неурядових організацій [6, с. 166]. Отже, від Австро-Угорської імперії та аж до початку Другої світової війни на чеських землях лібералізм, плюралізм і демократія були звичними для чехів, $\mathrm{i}$ вони, на думку Г. Зеленько, «наклали відбиток на традиції громадянської взаємодії» [2, с. 95];

- від приходу на чехословацьких землях до влади комуністів у 1948 р. спостерігається занепад неурядового сектору, різко зменшилася кількість громадських організацій. Комуністична влада взяла під контроль майже всі сфери суспільного життя, унеможливлюючи будь-які активні дії з боку населення. Проте, на думку Н. Марадик, «навіть комуністичний режим не зміг повністю знищити громадянську культуру чехословацького народу» [6, с. 164]. Кількість громадських організацій за комуністичного режиму зменшилась від 60 тисяч до 683-х. Легально діяли лише організації, підтримувані режимом;

- у часі режиму «реального соціалізму» розвивався самвидав, дисидентський рух. Найзначнішими подіями були «Празька весна» (1968р.) та протести 1989 р., які зумовили демократизацію. Знаковою постаттю на цьому етапі еволюції чеського громадянського суспільства $\epsilon$ один із найвідоміших дисидентів - В. Гавел: ще під час «Празької весни» він в ході політичних дебатів закликав до демократизації суспільства. Основу підпільного чеського громадянського суспільства становила «Хартія-77», на основі якої був створений «Громадянський форум»ініціатори демократичних перетворень 1989 р. На думку Н. Марадик, «у 1980-х роках відбулося своєрідне „пробудження” чехословацького суспільства» [6, с. 165]. «Оксамитова революція» почалася зі студентських протестів. Після 1968 р. якраз сформувалося нове покоління, «не обтяжене спогадами про репресії» [4, с. 18]. Це покоління не приховувало незадоволення існуючою системою державного управління, було достатньо сміливим щоб об'єднати незадоволених комуністичним режимом і виступити проти нього [15, с. 115].

Чеський дослідник П. Кірілі відзначає, що чеське суспільство було найпередовішим у Центрально-Східній Європі: таким воно було, і перед приходом до влади комуністів, і в 1989 р. Тим пояснюється легший перехід до ринкових відносин та імплементація демократичних цінностей. Соціалістичний лад був глибоко неприйнятним для чехів, що сприяло демократизації. Отже, наявність у чехів традицій громадянської взаємодії зумовила те, що «у 1990-х рр. у цій країні не стояло питання щодо заснування громадянської культури, потрібно було лише реставрувати ії» [6, с. 167]. Українська політолог Г. Зеленько чинниками, які сприяли розвитку громадянського суспільства в Чеській Республіці називає: швидкий темп руйнування соціалістичної системи; культурні традиції та ступінь суспільної самоорганізації; високий рівень соціально-економічного розвитку [2]. Уже в 1990 р. було унормована діяльність громадських організацій.

На відміну від Болгарії або ж України, Чехія рішуче поставила заслін колишній компартійній номенклатурі в іiі намірі продовжувати формально або ж неформально керувати країною. Це було зроблено шляхом багаторічної люстрації, розпочатої в жовтні 1991 р. (перший досвід у ЦентральноСхідній Свропі).

Відзначимо, що існували дві полярні концепції громадянського суспільства, представлені першим і другим президентами Чехії (до 1993 р. - Чехословаччини) - В. Гавелом і В. Клаусом [6, c. 165]. Якщо В. Гавел акцентував на надважливій ролі неурядових організацій, то В. Клаус 
розглядав основою політичної системи партії, а іншим акторам громадянського суспільства відводив порівняно незначне місце в політиці.

Чеське громадянське суспільство стрімко пройшло шлях від одиничних ініціатив до масового громадського руху. Наприклад, у 1993 р. у Чехії налічувалося уже 22,7 тис. НУО, у 1998 - 39,5 тис., 2008 - 52,6 тис. і т. д. Вкажемо на кілька особливостей чеського «третього сектора»:

- основу «третього сектора» становлять не політичні, правозахисні організації (до яких відносяться й антикорупційні як основний предмет нашого дослідження), а екологічні, культурні, спортивні, професійні асоціації та ін. Це загалом типово для структур новітніх громадянських суспільств, у яких сегмент антикорупційних структур незначний;

- великий відсоток у загальній кількості чеських НУО становлять «сплячі» організації, які свого часу створювалися «під проект», «під гранд» і под.;

- нерівномірний розподіл НУО територією країни; найбільша їх концентрація - «в Празі, Центральночеському краї та краї Височіна» [6, с. 167].

I. Ткаченко [9, с. 282-284] виділяє низку етапів еволюції чеського громадянського суспільства періоду демократизації: 1) період революційного ентузіазму (1990-1992); великою у цей час була роль іноземних донорів; 2) період коливань щодо векторів розвитку громадянського суспільства (1993-1996); зумовлений дебатами між В. Гавелом і В. Клаусом. На цьому етапі було посилено законодавчу базу функціонування та фінансування діяльності НУО; 3) значне зниження активності громадського сектора через збільшення регуляторного впливу держави на інституції громадянського суспільства (1997-2001); 4) проведена децентралізація чеської влади (як частина підготовки до вступу в СС) сприяла розвитку організацій громадянського суспільства в регіонах (2002-2004); 5) удосконалення системи функціонування «третього сектора» та його взаємодії 3 владою, унормування питання публічних контактів і консультацій, інкорпорація загальноєвропейських проблем у діяльність чеського громадянського суспільства (після 2004 р.).

На думку Н. Марадик, процес консолідації громадянського суспільства в Чеській Республіці ще не завершився, оскільки простежуються негативні тенденції, що заважають цьому. Однак очевидним $€$ те, що інституціональна модель громадянського суспільства, яка утвердилися в Чеській Республіці упродовж 1990-х - на початку 2000-х pp., є ефективною. Інститути громадянського суспільства виконують свою основну функцію - артикулюють інтереси громадян. У свою чергу населення позитивно ставиться до філософії та інститутів громадянського суспільства [5, с. 127].

Попри те, що вже три десятиліття чеські уряди протидіють корупції, п'ята частина чехів у соціологічних опитуваннях Євробарометра [14] стверджує, що хабарі є соціальною нормою (серед них значна частка респондентів-молоді, що вочевидь $\epsilon$ результатом негативно спрямованої соціалізації в межах родин, якими у період соціалізму був широко практикований корупційний прагматизм); 95 \% уважають, що корупція широко поширена в їхній країні, а 80\% називають протидію корупції найважливішим завданням уряду.

Чеський дослідник М. Цейп дійшов висновку, що хабарництво в Чехії перетворилося на загальновизнаний стиль життя: міра корумпованості в чеській спільноті настільки значна, що люди бояться іiї більше, ніж злочинності та безробіття; лише кожен десятий чех погодився б (лише за умови анонімності) свідчити в суді проти хабарника; третина населення долучена до більших чи дрібних корупційних оборудок [10]. Ситуація, коли чеська спільнота ставиться до корупції апатично і сприймає її як норму, загрозлива.

Попри те, що антикорупційні програми реалізовуються в Чехії починаючи від 1998 р., політична історія Чехія наповнена прикладами корупції високопосадовців, наприклад:

- у 2012 р. за корупційні дії були засуджені міністр транспорту В. Барта та депутат Я. Шкарка, але Верховний суд звільнив їх від відповідальності, бо вони скоїли злочин, перебуваючи в парламентській залі, тож на них поширюється депутатська недоторканність;

- в 2013 р. у ході великої антикорупційної спецоперації була затримана низка чеських високопосадовців: керівник секретаріату прем'єр-міністра Я. Надь, керуючий справами Кабінету міністрів Л. Поул, начальник військової розвідки генерал М. Кованду та ін. Серед звинувачень підозра у співпраці з олігархами й лобістами, через яких протеговані компанії отримували значні державні замовлення в обхід тендерним процедурам. Низка кримінальних справ довела зв'язки чеських політиків із мафіозними структурами. Парадокс у тому, що уряд П. Нечаса прийшов до влади у 2010 р. із великою антикорупційною програмою, але саме через корумпованість багатьох міністрів пішов у відставку, а корупційний скандал переріс у політичну кризу; 
- чеського прем'єр-міністра А. Бабіша (бізнес-олігарха, власника конгломерату 230 фірм агрохімічної галузі [17], а також медіа-імперії) в 2017 р. було звинувачено в зловживаннях розподілу субсидій $Є C$ [16]. Одна 3 компаній А. Бабіша в часі обіймання ним посади міністра фінансів (2014-2017) шахрайськи отримала 2 млн євро коштів ЄС на розвиток готельного комплексу «Гніздо лелеки» («Сарі Hnezdo»). Із посади міністра фінансів він був звільнений за підозрою в податковому шахрайстві, корупції та протизаконному впливі на медіа. Ймовірно, виправданими $\epsilon$ назви-маркери цього політика - «чеський Трамп» [17], «чеський Берлусконі». Примітно, що не зважаючи на кримінальну справу і позбавлення А. Бабіша (вересень 2017 р.) депутатського імунітету, він повернув собі цей імунітет після перемоги на парламентських виборах (жовтень 2017 р.); очолюваний А. Бабішем популістський і м'яко євроскептичний рух ANO 2011 переміг на парламентських виборах. Ще один парадокс у тому, що А. Бабіш, якого звинувачують у корупції, побудував свою останню виборчу кампанію на антикорупційних гаслах.

Водночас відзначимо, що Чехія за 2017 р. дещо покращила свою позицію в щорічному Індексі сприйняття корупції Transparency International, піднявшись із 55 балів до 57 (42 місце). Попри те, що показники Чехії нижчі за середні по $Є \mathrm{C}$, за останні шість років $\epsilon$ істотні позитивні зрушення в напрямку мінімізації корупційних практик (у 2012 р. було набрано лише 49 балів). Проте зберігається низка проблем, законодавчих прогалин, які є простором антикорупційних ініціатив чеського громадянського суспільства. Прикладом може слугувати питання відсутності унормування лобіювання, що зумовлюе політичну корупцію у законодавчому процесі. Громадськість виступила 3 ініціативами призупинення небажаного впливу на законодавчий процес завдяки унормуванню цього питання.

Чеський уряд досі не запропонував будь-які значні антикорупційні реформи, які були б широко підтримані громадськістю. Натомість впроваджуються норми, які істотно не відрізняються від уже існуючих, виражене зволікання у прийнятті певних антикорупційних актів [12, с. 39]. Відсутність ефективного законодавства в цілому зумовлює недостатню ефективність протидії корупції [11, c. 2-3]. Чеське суспільство має традиційно низький рівень довіри органам державної влади. «Широко вкорінена корупція та погане керування державними ресурсами [...] значно зменшують легітимність і функціонування існуючого демократичного режиму» [8, с. 32]. Але саме це сприяло появі сильного лобі акторів громадянського суспільства, які тиснуть на державні інституції у вимозі запровадження прозорих процедур, які б мінімізували корупцію.

Зауважимо: попри істотні проблеми корупційного характеру в Чехії, у цій державі, на відміну від низки країн Центрально-Східної Європи, відбулися лише поодинокі антикорупційні масові акції протесту. Наприклад, у травні 2017 р. у чеських містах пройшли доволі великі акції протесту 3 вимогами відставки президента М. Земана та міністра фінансів А. Бабіша. Натомість доволі значними $\epsilon$ антикорупційні ініціативи чеського «третього сектора», зокрема, антикорупційної платформи «Реконструкція держави» (Rekonstrukce STATU; RotS), «Frank Bold», «Центру прикладної економіки» («Zindex»), «Відродження» («Oživení») та ін. Однією 3 найперших і найдієвіших антикорупційних організацій є Transparency International - Česká republika, яка діє від 1998 p.

Однією 3 найвідоміших антикорупційних кампаній чеського громадянського суспільства $\epsilon$ національна антикорупційна платформа «Реконструкція держави» (http://www.rekonstrukcestatu.cz/cs). Вона реалізовується від 2012 р. за участю понад 20 чеських НУО та підтримується міжнародними грандами, народним краудфандингом. Численні корупційні справи проти чеських топ-чиновників зумовили розробку дев'яти антикорупційних законопроектів, а саме щодо: прозорості фінансування політичних партій; майнових декларацій під час вступу на посаду; контрактів в Інтернеті; скасування анонімних акцій; призначень членами правління державних компаній; незалежного державного управління, відсутності політичного втручання у кримінальні розслідування; прозорості законодавчого процесу; розширення повноважень Вищого бюро аудиту. Частина зі зазначених законопроектів уже трансформовані в чинні закони. Згадані законотворчі пропозиції чеської антикорупційної платформи «Реконструкція держави» спонукали появу кількох схожих ініціатив у інших країнах Центрально-Східної Європи, наприклад, в Угорщині (Ez a minimum a korrupció ellen), Словаччині (Štrngám za zmenu!).

Організації, які є учасниками платформи «Реконструкція держави», здійснюють й самостійні антикорупційні ініціативи. Наприклад, «Frank Bold» протидіючи системній корупції в Чехії, забезпечує юридичне консультування, захист у справах, які стосуються корупції, а також працює над прийняттям законів, програм, які допомагають громадянам контролювати уряди, забезпечувати відкритість, прозорість прийняття публічних рішень. Зокрема, «Frank Bold» у 2015 р. виступила 
основним лобістом прийняття закону, за яким усі державні контракти мають бути зареєстровані та доступні для ознайомлення. Робота «Frank Bold» нині зосереджена на контролі за політиками, державними службовцями в частині розпорядження державними активами, зловживання ними задля нецільового фінансування (потреби партії, виборча кампанія тощо).

Також відзначимо діяльність «Центру прикладної економіки» (Centrum aplikované ekonomie, інша назва організації - «Zindex») та організації «Oživení». Неурядова організація «Zindex» діє з 2011 року зусиллями дослідників Карлового університету в Празі; спеціалізується на виявленні корупції в державних закупівлях. Неурядова організація «Оživení», створена в 1997 р., здійснює антикорупційне консультування, антикорупційний аудит, вироблення антикорупційних стратегій.

Залученості громадянського суспільства Чехії до протидії корупції сприяла низка нормативних актів, найперше Закон «Про вільний доступ до інформації» (1999 р., зі змінами 2002 р.), Закон «Про державні закупівлі» (у редакції 2012 р.) та ін. Чеське громадянське суспільство активізовувалося спершу з вимогами прийняття цих актів, а згодом - щодо внесення змін до них, розробки механізмів їх реального впровадження. Наприклад, Закон «Про державні закупівлі» зумовив низку громадських ініціатив щодо «нових правил і створення Централізованого реєстру контрактів державних закупівель, який запроваджував сучасну систему загальнодоступних контрактів, укладених органами державного управління та державними компаніями» [8, с. 23]. Ще однією темою ініціатив акторів громадянського суспільства був Закон «Про державну службу», який попри прийняття ще у 2002 р. (на виконання євроінтеграційних вимог) до 2015 року неодноразово відкладався до впровадження. У результаті Чехія «була єдиною країною-членом $\mathrm{CC}$, що мала непрацюючий закон про державну службу» [8, с. 26]. Фактично штучно зберігалися умови, за якими була відсутня незалежна, ефективна та деполітизована державна служба. На цій проблемі постійно акцентували такі організації та громадські ініціативи, як «Реконструкція держави», «Інвентаризація демократії» та Transparency International - Česká republika та ін.

Одним із напрямків діяльності антикорупційних організацій є створення та обслуговування «гарячих ліній». Наприклад, у 2007-2010 рр. таку антикорупційну лінію вперше організувала й обслуговувала Transparency International - Česká republika. Згодом номер 199 почав обслуговуватися громадською організацією «Oživení» [13].

Досвід Чехії засвідчує: роль громадянського суспільства в просуванні реформ у протидії корупції може бути достатньо значною. Без акторів громадянського суспільства в Чехії унеможливилося б публічне обговорення теми корупції та змушування політиків уважати ці питання релевантними.

\section{Бібліографічний список:}

1. Бевзюк С. В. Становлення та утвердження «Чеської матиці» як національно-просвітницького центру на землях Богемського королівства / Є. В. Бевзюк // Гілея. - 2013. - № 72. - С. 200-206.

2. Зеленько Г. Взаємозалежність фаз демократизації і становлення громадянського суспільства у постсоціалістичних країнах / Г. Зеленько // Сучасна українська політика. Політики і політологи про неї. 2007. - № 10. - C. 86-100.

3. Зеленько Г. І. Інституціоналізація громадянського суспільства у постсоціалістичних країнах (на прикладі країн Вишеградської групи та України): автореф. дис. ... д-ра політ. н.: 23.00.02 / Галина Іванівна Зеленько. - К. : ІПіЕНД ім. І. Ф. Кураса НАН України, 2007. - 36 с.

4. Кірілі П. Модель посткомуністичної трансформації Чеської Республіки / П. Кірілі // Трансформаційні процеси у країнах Вишеградської групи та Україні: порівняльний аналіз. - К. : Стилос, 2013. - C. 16-30.

5. Марадик Н. Особливості процесу переходу до демократії в Чеській республіці / Н. Марадик // Наук. вісн. Ужгород. ун-ту. - Сер. «Політологія, соціологія, філософія». - 2009. - № 13. - С. $125-128$.

6. Марадик Н. Тенденції та перспективи розвитку громадянського суспільства в Чеській Республіці / Н. Марадик // Наук. вісн. Ужгород. ун-ту. - Сер. «Політологія, соціологія, філософія». - 2009. - № 12. C. $164-168$.

7. Приходько В. П. Трансформація масових громадянських рухів у Чехії та Словаччині в 1990-1991 рр.: порівняльний аналіз партійно-політичної структуризації / В. П. Приходько // Carpatica Карпатика. - 2002. - № 16. - С. 283-293.

8. Ріхачкова В. Чеська Республіка: прозорість політичних інституцій та роль європейських інтеграційних процесів у підвищенні їх відкритості / В. Ріхачкова, В. Кріж // Шлях до ЄС Вишеградських країн: уроки для України. - К. : Фонд «Демократичні ініціативи імені Ілька Кучеріва», 2015. - С. 22-37.

9. Ткаченко I. В. Особливості функціонування громадянського суспільства у Чеській Республіці / І. В. Ткаченко // «Третя хвиля» демократизації на теренах Свразії: досвід новітньої історії та виклики сучасності. - К.: Фенікс. - С. 277-284. 
10. Шатилов М. Чехія: корупція як засіб проти корупції [Електронний ресурс]. - Режим доступу: http://p.dw.com/p/19DIx

11. Heeks R. Understanding Success and Failure of Anti-Corruption Initiatives [Електронний ресурс]. Режим доступу: https:/www.cmi.no/publications/file/3978-understanding-success-and-failure-of-anti.pdf

12. Hetterich R. Czech Public Procurement: the Fight Against Corruption / R. Hetterich // Post-Communist Reform in the Czech Republic: Progress and Problems. - 2016. - № 4. - C. 35-43.

13. Initiatives and practices of the Czech Republic in the area of prevention of corruption [Електронний peсурс]. - Режим доступу: https:/www.unodc.org/documents/treaties/UNCAC/WorkingGroups/workinggroup4/ 2011-August-22-24/Replies_to_CU_2011_45/20110513_Czech_Republic_English.pdf

14. Lazarová D. A fifth of $\bar{C}$ zechs consider bribes to be a normal part of life [Електронний ресурс]. - Режим доступу: http://www.radio.cz/en/section/curraffrs/a-fifth-of-czechs-consider-bribes-to-be-a-normal-part-of-life

15. Simral V. The Games of the Velvet Revolution: An Integrative Approach to the Transition in Czechoslovakia 1989 / V. Simral // Perpetual motion? Transformation and Transition in Central and Eastern Europe \& Russia / T. Bhambry, C. Griffin, JTO Hjelm, C. Nicholson, OG. Voronina (Eds.). - London: School of Slavonic and East European Studies. - C. 115-133.

16. Tait R. Czech government resigns as PM fights corruption allegations // The Guardian. - 2018. - 17 Jan.

17. Tait R. Trump-style billionaire populist on brink of power in Czech Republic // The Guardian. - 2018. 22 Oct.

Kabantseva I. A. The ,third sector" of the Czech Republic as an actor of anti-corruption policy

The author notes that despite the rapid pace of reforms in the Czech Republic during the last three decades, the high level of corruption constrains effective modernization of the country. It is emphasized that the Czech civil society is an active lobbyist for anti-corruption initiatives. The article: 1) determines the level of development, the degree of formation of the civil society of the Czech Republic; 2) investigates the extent of damaging impact of the destructive institution of corruption on the country; 3) studies the influence of the constructive institution of the Czech civil society on the destructive institution of corruption. It is noted that, despite the high level of corruption in the Czech Republic, unlike some other Central and Eastern European countries, mass anti-corruption protests are rare in this country. On the other hand, there are significant anti-corruption initiatives of the Czech "third sector", particularly the anti-corruption platform Rekonstrukce STATU (RotS), Transparency International - Česká republika, Frank Bold, Zindex, Oživeni, etc. The article analyzes the activities of the anti-corruption platform RotS, which unites over 20 $N G O s$ and is focused on the development of anti-corruption bills. It is noted that the legislative proposals of RotS led to the emergence of a number of public initiatives in other Central and Eastern European countries (for example, Ez a minimum a korrupció ellen in Hungary, Štrngám za zmenu! in Slovakia, etc.). The article analyzes the anti-corruption initiatives of the Frank Bold human rights organization, which provides legal counseling, legal protection in corruption cases, lobbies for bills aimed at controlling the government and ensuring transparency of public decision-making, primarily when it comes to state contracts. It studies the activities of Zindex (specialized on detecting corruption in government procurements) and Oživeni (providing anti-corruption counseling, anti-corruption audit, development of anti-corruption etc.). It is argued that the experience of the Czech Republic demonstrates the significant potential of the civil society in corruption counteraction. Without the civil society actors in Czech Republic it would be impossible to publicly discuss the corruption issues, or to force politicians to consider these issues relevant.

Key words: Czech Republic, anti-corruption NGOs, anti-corruption public initiatives. 